\title{
Makna Kebahagiaan pada Generasi Y
}

\author{
Nina Zulida Situmorang ${ }^{1}$, Fatwa Tentama ${ }^{2}$ \\ Magister Psikologi Universitas Ahmad DahlanYogyakarta \\ ${ }^{1}$ nina.situmorang@psy..uad.ac.id \\ ${ }^{2}$ fatwa.tentama@psy.uad.ac.id
}

\begin{abstract}
Abstrak
Latar belakang: Manusia pada hakekatnya menempatkan kebahagiaan sebagai tujuan hidup. Penelitian kebahagiaan merupakan bahasan paling banyak diteliti dan sangat penting dibidang psikologi dalam era milenium yang sejalan dengan berkembangnya bidang kajian positive psychology. Penelitian-penelitian mutakhir menyebutkan bahwa tidak semua teoriteori psikologi sesuai disuatu daerah yang sebenarnya berkaitan dengan nilai-nilai masyarakat dan daerah yang dianut. Generasi Y sebagai generasi yang memiliki kelekatan pada sosial media memiliki cara pandang tersendiri mengartikan kebahagiaan. Tujuan: Penelitian ini bertujuan untuk memahami dan mendeskripsikan makna kebahagiaan yang dirasakan oleh pada mahasiswa Pascasarjana sebagai generasi $\mathrm{Y}$ dengan pendekatan Psikologi Indigenous dalam upaya membuat suatu teori psikologi menjadi relevan apabila diterapkan didaerah atau konsteks budaya lain. Metode: Metode penelitian dilakukan dengan metode kuantitatif deskriptif dengan prinsip constructive realism. Subjek penelitian 28 mahasiswa Pasca sarjana Yogyakarta. Data dikumpulkan dengan menggunakan kuesioner terbuka kemudian data penelitian dianalisis dengan memadukan hasil kategorisasi data text. Hasil: Hasil penelitian menghasilkan enam kategorisasi tentang makna kebahagiaan generasi Y menurut subjek yaitu sehat secara emosi sebesar 28.6\%, hubungan positif dengan keluarga dan orang lain sebesar $21.4 \%$, materi sebesar $14.3 \%$, melakukan kegiatan positif sebesar $14.3 \%$, sehat secara jasmani sebesar $10.7 \%$ dan kebersyukuransebesar $10.7 \%$. Simpulan: Generasi Y pada pada penelitian ini memberi makna kebahagiaan yakni dalam kondisi sehat secara emosi, memiliki hubungan positif dengan keluarga dan orang lain, memiliki materi, melakukan kegiatan positif, memiliki kesehatan jasmani dan selalu bersyukur untuk setiap hal yang dimiliki.
\end{abstract}

KATAKUNCI: makna kebahagiaan, generasi Y, Psikologi Indigenous

\begin{abstract}
Background: Humans essentially put happiness as the purpose of life. Happiness research is the most researched and critical topic in the field of psychology in the millennium in line with the development of the field of study of positive psychology. Recent studies state that not all psychological theories are appropriate in an area that is related to the values of the community and the city adopted. Generation $\mathrm{Y}$ as a generation that has an attachment to social media has its perspective to interpret happiness. Objective: This study aims to understand and describe the meaning of happiness that is felt by Postgraduate students as generation $\mathrm{Y}$ with an Indigenous Psychology approach to making a psychological theory relevant if applied in other areas or cultural contexts. Method: The research method was carried out using a descriptive quantitative method with the principle of constructive realism. The research subjects were 28 Yogyakarta Postgraduate students. Data was collected using an open questionnaire, and the research data was analyzed by combining the results of text data categorization. Results: The results of the study resulted in six classifications of the meaning of generation $\mathrm{Y}$ happiness according to the subject that is emotionally healthy by $28.6 \%$, positive relationships with family and others by $21.4 \%$, material by $14.3 \%$, positive activities
\end{abstract}


by $14.3 \%$, physically healthy by $10.7 \%$ and Thanksgiving is $10.7 \%$. Conclusion: Generation $\mathrm{Y}$ in this study gives meaning to happiness that is in an emotionally healthy condition, has a positive relationship with family and other people, has material, has positive activities, has physical health and is always grateful for everything that is owned.

KATAKUNCI: the meaning of happiness, generation Y, Indigenous Psychology

\section{Pendahuluan}

Setiap manusia pada dasarnya menginginkan hidup bahagia sebagai tujuan hidupnya tidak terkecuali pada individu generasi milineal yakni gen Y. Kebahagiaan subjektif menjadi begitu penting karena dianggap tujuan akhir dari kehidupan. Orang yang bahagia memandang dunia lebih aman, membuat keputusan lebih mudah, menilai pelamar kerja lebih baik, lebih kooperatif, dan hidup lebih sehat, lebih enerjik, dan lebih memuaskan (Lyubomirsky, Kasri, \& Chang, 2002; Myers, 1993). Kondisi sekarang menunjukkan kondisi yang semakin sulit secara ekonomi, ataupun mengalami problema dalam interaki dengan orang lain. Segala upaya dilakukan untuk mendapatkan kebahagiaan yang dapat berujung pada kondisi stres, depresi atau dengan cara-cara yang membahayakan dirinya dan orang lain. Generasi Y istilah yang digunakan untuk menggambarkan kelompok individu yang lahir setelah generasi $\mathrm{X}$. Generasi yang dianggap sebagai generasi yang paling tanggap dengan teknologi masa kini. Generasi yang lahir antara tahun 1980 hingga 2000, yaitu mereka yang berusia sekitaran 17 37 tahun. Generasi Y pada tahun 2020 akan membentuk 60\% angkatan kerja secara global. (Pricewaterhouse Coopers International Limited, 2011). Generasi Y atau generasi milineal dapat dilihat berdasarkan tahun kelahirannya yakni generasi yang lahir tahun 1980 hingga tahun 2000 (De Meuse, Mlodzik \& Korn, 2010).

Survei yang dilakukan JobStreet.com Indonesia (2016) rentang bulan Juni-Juli 2016 kepada 27.000 responden mengenai motivasi kebahagiaan di tempat bekerja menunjukkan gambaran kebahagiaan pada generasi Y. Hasil survei mengungkapkan, 33,4 persen responden yang dengan rentang usia 22-26 tahun, dan pengalaman bekerja $1-4$ tahun, menyatakan mereka tidak bahagia di tempat kerja. Tiga faktor utama yang memberikan ketidakbahagiaan tersebut yakni, kesempatan pengembangan karier yang terbatas, jumlah insentif yang kurang menggiurkan serta gaya kepimimpinan manajemen yang kaku. Hal ini menunjukkan kebahagiaan pada generasi Y sebagai pekerja cenderung pada hal-hal yang bersifat artifisial cenderung pada material yakni berupa tunjangan finansial yang membuat para pekerja Generasi Y untuk merasa bahagia di tempat bekerja.

Penelitian ini mengartikan kebahagiaan dengan subjective well being yang menunjukkan peningkatan dari tahun ke tahun dan menempatkan Seligman sebagai peneliti yang 
mempublikasikan psikologi positif sebagai arah dan orientasi baru dalam ilmu psikologi, yang menjadikan kesejahteraan sebagai kajian utamanya (Compton, 2005). Psikologi positif melihat individu mampu menentukan cara memandang kehidupan yang berpusat pada pemaknaan hidup yang bersifat sangat subjektif. Pada akhirnya pemaknaan hidup yang positif dapat meraih kebahagiaan. Seligman (2005) berpendapat bahwa di tengah ketidakberdayaannya, manusia selalu memiliki kesempatan untuk melihat hidup secara lebih positif.

Kebahagiaan subjektif secara ilmiah diartikan bagaimana seseorang menilai kehidupan mereka baik saat ini dan tahun-tahun sebelumnya (Diener, Oishi, \& Lucas, 2003). Evaluasi penilaian kehidupan mencakup reaksi emosional seseorang terhadap suatu kejadian, mood dan penilaian mereka terhadap kepuasan hidup, fulfillment, kepuasan perkawinan dan kepuasan kerja. Kebahagiaan (happiness) lebih menekankan pada aspek afeksi positif atau emosi positif yang dirasakan individu cenderung ke arah objektif. Kebahagiaan subjektif tidak hanya menyangkut aspek emosi atau perasaan namun juga meliputi penilaian seseorang tentang hidupnya dan cenderung ke arah subjektif (Rakhmat, 2006). Sebagian penelitian menyebut istilah subjective well-being dengan kebahagiaan, dengan kata lain kebahagiaan adalah alternatif lain dari subjective well-being (Argyle, 2001).

Generasi Y di Indonesia menjadi bagian terbesar dari tenaga kerja yakni didominasi oleh golongan umur mulai dari 20-24 tahun hingga yang 30-34 tahun (Badan Pusat Statistik, 2016). Kebahagian pada generasi Y menjadi penting untuk diteliti karena memberi dampak penting pada perkembangan ekonomi Indonesia. Orang yang bahagia memandang dunia lebih aman, membuat keputusan lebih mudah, menilai pelamar kerja lebih baik, lebih kooperatif, dan hidup lebih sehat, lebih enerjik, dan lebih memuaskan (Lyubomirsky, Kasri, \& Chang, 2002; Myers, 1993). Salah satu kunci keberhasilan mereka adalah tingginya kebahagiaan subjektif, jika tingkat kebahagiaan subjektif tinggi maka mereka akan menunjukan kemampuan tinggi dalam pekerjaan. Ketika bahagia, individu lebih suka membantu orang lain karena pengalaman yang membahagiakan seperti mendapat uang, berhasil menjalankan tugas yang menantang, mengenang saat bahagia membuat orang lebih besar kemungkinannya untuk memberikan sumbangan, mengorbankan waktunya dan sebagainya. Berdasar latar belakang tersebut penelitian ini bertujuan untuk melihat apa yang menjadi makna kebahagiaan generasi Y.

\section{Landasan Teori}

\section{Kebahagiaan Subjectif}


Diener dan kawan-kawan (2003) mendefenisikan kebahagiaan sebagai suatu penilaian seseorang terhadap kehidupan mereka baik saat ini dan tahun-tahun sebelumnya. Evaluasi ini mencakup reaksi emosional seseorang terhadap suatu kejadian, mood dan penilaian mereka terhadap kepuasan hidup, fulfillment dan kepuasan perkawinan dan kepuasan kerja. Individu dengan kebahagiaan tinggi akan lebih mampu mengatasi dan mengontrol emosi dalam dirinya dan mampu dengan lebih baik menghadapi hidup di masa mendatang. Individu yang level kebahagiaan rendah sebaliknya akan memandang peristiwa yang terjadi dalam hidupnya sebagai peristiwa yang tidak menyenangkan sehingga menimbulkan emosi negatif pada dirinya (Diener, dkk., 2003). mendefinisikan kebahagiaan subjektif sebagai cara individu mengevaluasi kehidupannya dan terdiri dari beberapa variabel, seperti kepuasan hidup dan kepuasan pernikahan, rendahnya tingkat depresi dan kecemasan, serta adanya emosi dan suasana hati yang positif.

Kebahagiaan subjektif menjadi begitu penting karena dianggap tujuan akhir dari kehidupan. Orang yang bahagia memandang dunia lebih aman, membuat keputusan lebih mudah, menilai pelamar kerja lebih baik, lebih kooperatif, dan hidup lebih sehat, lebih enerjik, dan lebih memuaskan (Lyubomirsky, Kasri, \& Chang, 2002; Myers, 1993). Ketika bahagia, individu lebih suka membantu orang lain karena pengalaman yang membahagiakan seperti mendapat uang, berhasil menjalankan tugas yang menantang, mengenang saat bahagia membuat orang lebih besar kemungkinannya untuk memberikan sumbangan, mengorbankan waktunya dan sebagainya.

\section{Metode Penelitian}

Metode penelitian menggunakan metode kuantitatif deskriptif dengan pendekatan psikologi indijinus dengan prinsip constructive realism. Pendekatan constructive realism merupakan pendekatan dengan prinsip suatu konstruk dibangun berdasar kondisi nyata subjek penelitian. Kelebihan pendekatan ini dapat menghasilkan konstruk teori sesuai dengan kondisi masyarakat dan budaya subjek.

\section{Partisipan}

Subjek penelitian adalah Mahasiswa Magister Psikologi Universitas Ahmad Dahlan Yogyakarta dengan latar belakang beragam budaya. Jumlah subjek 28 mahasiswa yang terdiri 22 perempuan dan 6 laki-laki. Range usia 22 sampai dengan 30 tahun. Pengambilan sampel dilakukan dengan teknik purposive sampling.

\section{Pengukuran}

Penelitian ini menggunakan kuesioner terbuka dengan pertanyaan: Tuliskan 5 kata makna kebahagiaan dan jelaskan alasannya. Setiap subjek akan memberi 5 respon jawaban. 


\section{Prosedur}

Penelitian dilakukan pada 2 kelompok mahasiswa. Kelompok 1 terdiri dari 12 mahasiswa dan kelompok 2 terdiri dari 23 mahasiswa. Setiap kelompok diberikan pertanyaan terbuka dan menuliskan jawaban di lembar yang telah disediakan dan dilanjutkan dengan proses kategori data dari semua jawaban subjek berdasarkan kata kunci, similaritas respon dan maknanya. Hasil kategorisasi setiap kelompok digabungkan.

\section{Analisis data}

Data penelitian dilakukan dengan proses multirespon dimana jumlah data tidak berarti sama dengan jumlah responden yang mengisi kuesioner. Ada 140 respon jawaban yang dihasilkan dari responden. Setelah proses koding dilanjutkan dengan komputasi sederhana untuk menghitung persentase. Data ditampilkan dalam tabel persentasi.

\section{Hasil penelitian}

Hasil penelitian dibagi dua kelompok kategorisasi yaitu pertama makna kebahagiaan pada generasi $\mathrm{Y}$ ditimbulkan dari faktor eksternal yakni hubungan positif dengan keluarga/orang lain, materi, melakukan kegiatan positif dan materi. Kedua, makna kebahagiaan generasi Y muncul dari faktor internal berupa sehat secara emosi, sehat secara jasmani dan kebersyukuran..

Hasil penelitian menghasilkan enam kategorisasi makna kebahagiaan generasi Y dari hasil 2 kali proses kategorisasi berdasar 2 kelompok yaitu 1) sehat secara emosi, 2) hubungan positif dengan keluarga dan orang lain, 3) materi, 4) Melakukan kegiatan positif, 5) sehat secara jasmani dan 6) kebersyukuran. Hasil persentase dilihat di Tabel 1 di bawah ini.

\section{Tabel 1}

\section{Kategori Makna Kebahagiaan Generasi Y}

\begin{tabular}{ll}
\hline Makna Kebahagiaan & Persentase \\
\hline Sehat Emosi & 28.6 \\
Hubungan Positif dengan keluarga dan orang lain & 21.4 \\
Materi & 14.3 \\
Melakukan aktifitas & 14.3 \\
Sehat Jasmani & 10.7 \\
Kebersyukuran & 10.7 \\
\hline
\end{tabular}

Pembahasan 
Hasil penelitian mendukung hasil penelitian yang dilakukan oleh Patnani (2012) bahwa sumber kebahagiaan subjek pada rentang umur 21-29 tahun adalah keluarga, materi, keinginan, teman, orang dekat, makan, jalan-jalan, anak, berbagi, hidup tenang, dan sikap yang apa adanya. Peneliti membuat dua kelompok kategorisasi yaitu pertama, kebahagiaan yang ditimbulkan dari faktor eksternal berupa hubungan positif dengan keluarga dan orang lain, materi dan karier, serta kegiatan positif yang dilakukan. Kedua, kebahagiaan yang ditimbulkan dari faktor internal berupa sehat secara emosi dan sehat secara jasmani dan rohani. Hal ini membuktikan kebahagiaan generasi Y dimaknai lebih banyak pada faktor eksternal.

Tabel 1 menunjukkan bahwa kebahagiaan generasi Y menurut subjek lebih banyak ditentukan oleh sehat secara emosi dengan persentase 28.6\%. Sehat secara emosi ini lebih kepada rasa bersyukur dengan apa yang dimiliki, perasaan cinta dan kasih sayang kepada orang-orang terdekat. Kebahagiaan dimaknai dengan ketenangan batin artinya tidak ada gangguan dari luar.

Makna kebahagiaan generasi Y kedua adalah hubungan positif dengan keluarga dan orang-orang terdekat yakni diperoleh persentase sebesar $21.4 \%$. Seperti pada hasil penelitian Elfida, Lestari, Diamera, Anggraeni, dan Islami (2014) memperlihatkan bahwa sebagian besar responden $(49,9 \%)$ menganggap relasi positif merupakan faktor utama yang membuat bahagia dan kategori keluarga merupakan kategori yang paling mendukung dan membuat responden bahagia dengan persentase sebesar $(66,7 \%)$. Sejalan dengan penelitian Wulandari dan Widyastuti (2014), bahwa subjek akan merasa bahagia (terutama di tempat kerja) apabila menjalin hubungan positif dengan orang lain yang menunjukkan persentase sebesar 47,2\% . Untuk kategori relasi positif pada penelitian, kebersamaan dengan teman dan keluarga merupakan repson yang paling banyak diberikan responden.

Makna kebahagiaan generasi Y menurut subjek, berikutnya adalah sehat jasmani, artinya kebahagiaan yang timbul dari internal subjek, kategori ini memiliki persentase sebesar 10.7\%. Pada penelitian yang dilakukan Elfida dkk (2014) menyebutkan bahwa sebanyak 2,7\% subjek saat melakukan kegiatan religius atau spiritual akan menimbulkan kebahagiaan. Menurut Anggoro dan Widhiardo (2010), kebutuhan spiritual mengacu pada proses memenuhi atau telah terpenuhinya target individu dalam hal spiritual, yang mencangkup aktivitas-aktivitas yang mencerminkan keyakinan terhadap agama. Subjek pada penelitian ini mengungkapkan bahwa Allah SWT merupakan sumber kebahagiaan dan tempat keluh kesah untuk mengadu dan merasa lebih tenang dan nyaman, dan memiliki hubungan baik dengan Tuhan YME. Tidak lepas dari sehat secara rohani, terdapat sehat secara jasmani yakni sehat 
secara fisik, artinya tubuh yang sehat merupakan salah satu faktor kebahagiaan, dengan tubuh yang sehat subjek mampu melakukan banyak hal.

Selanjutnya kebahagiaan generasi Y menurut subjek menunjukkan makna yaitu memperoleh materi atau finansial dan karier dalam pekerjaan yang memadai. Kategori ini memiliki persentase sebesar $14.3 \%$. Subjek merasa bahagia dengan materi atau finansial yang tercukupi dan karier/pekerjaan yang baik. Pada penelitian Patnani (2012) menyebutkan hasil penelitian bahwa salah satu sumber kebahagiaan adalah materi atau dengan kata lain tercukupi materi yang diperoleh subjek.

Makna lain kebahagian generasi Y menurut subjek adalah kegiatan/aktifitas positif yang memiliki persentase sebesar 14.3\%. Kategori ini ditimbulkan dari faktor eksternal yang terdiri dari travelling atau jalan-jalan, kegiatan positif seperti membantu orang lain dan kegiatan sosial dan lainnya, serta kegiatan yang disenangi subjek seperti melakukan hobinya. Aktifitas-aktifitas tersebut menunjukkan gaya khas aktifitas generasi $\mathrm{Y}$ yang senang dengan kegiatan luar. Selain itu generasi Y memberi makna kebahagiaan dengan melakukan pencapain secara pribadi. Pencapaian pribadi mencakup terpenuhinya atau sedang dalam proses memenuhi keinginan pribadi secara umum, seperti cita-cita, kesejahteraan atau kepuasan terhadap kehidupan saat ini. (Anggoro \& Widhiarso, 2010).

Kemudian terakhir makna kebahagiaan pada generasi Y adalah rasa kebersyukuran sebesar $10.7 \%$. Respon kebersyukuran subjek antara lain mensyukuri apa yang Allah berikan pada kita, ketika saya mampu mensyukuri segala sesuatu yang telah saya miliki. Dan selalu bersyukur apapun keadaan karena tidak semua orang seberuntung kita. Pada penelitian yang dilakukan Sativa dan Helmi (2013) menghasilkan bahwa rasa syukur memberikan sumbangan sebesar 6,5\% (dari 163 subjek) terhadap kebahagiaan. Penelitian lain juga menunjukkan bahwa kebersyukuran memiliki hubungan dengan subjective well-being (Chan, 2013).

\section{Kesimpulan}

Penelitian ini menghasilkan enam kategorisasi tentang kebahagiaan generasi Y menurut subjek yaitu Generasi Y pada pada penelitian ini memberi makna kebahagiaan yakni dalam kondisi sehat secara emosi, memiliki hubungan positif dengan keluarga dan orang lain, memiliki materi, melakukan kegiatan positif, memiliki kesehatan jasmani dan selalu bersyukur untuk setiap hal yang dimiliki. 


\section{Daftar Pustaka}

Argyle, M. (2001). The Psychologi of Happiness. Sussex : Routledge.

Anggoro, W. J., dan Widhiarso, W. (2010). Konstruksi dan Identifikasi Properti Psikometris Instrumen Pengukuran Kebahagiaan Berbasis Pendekatan Indigenous Psychology: Studi Multitrait-Multimethod. Jurnal Psikologi 37(2): 176-188.

Badan Pusat Statistik. (2016). Penduduk berumur 15 tahun keatas menurut golongan umur dan jenis kegiatan selama seminggu yang lalu. Diunduh dari www.bps.go.id : https://www.bps.go.id/linkTabelStatis/view/id/974 tanggal 12 Juni 2018

Chan, D. W. (2013). Subjective well-being of Hong Kong Chinese teachers: The contribution of gratitude, forgiveness, and the orientations to happiness. Teaching and Teacher Education, 32: 22-30. doi: 10.1016/j.tate.2012.12.005

Compton, W. C. (2005). Introduction To Positive Psychology. Belmont: Thomson Learning.

De Meuse, K. P., Mlodzik, K. J., \& Korn. (2010). A second look at generational differences in

the workforce: implication for HR and talent management. People and Strategy, 50 58.

Diener, E., Suh, E., \& Oishi, S. (1997). Recent findings on subjective well-being. Indian Journal of Clinical Psychology, 24, 25-41.

Diener, E., Oishi, S., \& Lucas, R. E. (2003). Personality, culture, and subjective well-being: Emotional and cognitive evaluations of life. Annual Review of Psychology, 54, 403425.

Elfida, D., Lestari, Y.I., Diamera, A., Anggraeni, R., Islami, S. (2014). Hubungan Baik Dengan Orang yang Signifikan dan Kontribusinya Terhadap Kebahagiaan Remaja Indonesia. Jurnal Psikologi 10(2): 66-73.

JobStreet.com (2016) Happiness Index Survey 2017, diunduh dari https://wp.jsstatic.com/wp-content/uploads/sites/7/2017/11/survey.png pada tanggal 1 Juni 2018 .

Lyubomirsky, S., Kasri, F., \& Chang, O. (2002). Ruminative style and delay of presentation of breast cancer symptoms. Manuscript in preparation.

Myers, D. G. (1993). The pursuit of happiness. Scientific American, 52, 70-72.

Pricewaterhouse Coopers International Limited . (2011, April). Millennials at work:

Reshaping the Workplace, diunduh dari PwC: http://pwc.to/1QiIHGJ pada tanggal 10 Juni 2018.

Patnani, M. (2012). Kebahagiaan pada Perempuan. Jurnal Psikogenesis 1(1): 56-64

Rakhmat, J. (2006). Meraih Kebahagiaan.. Bandung: Sibiosa rekatama Media.

Sativa, A. R. \& Helmi, A. F. (2013). Syukur dan Harga Diri dengan Kebahagiaan Remaja. Jurnal Wacana 5(10). Diunduh pada tanggal 23 Mei 2018 dari http://jurnalwacana.psikologi.fk.uns.ac.id.

Seligman, M.E.P. (2005). : Menciptakan kebahagiaan dengan Psikologi Positif. Bandung: Penerbit Mizan.

Wulandari, S., \& Widyastuti, A. (2014). Faktor-Faktor Kebahagiaan di Tempat Kerja. Jurnal Psikologi 10(1): 49-60. 